Original Research Paper

\title{
American Students in Russia: Research and Data Analysis of Exchange Programs
}

\author{
${ }^{1}$ Alexander Aref'ev and ${ }^{2}$ Mara Sukholutskaya \\ ${ }^{1}$ Center for Sociological Research, Ministry of Education and Science, Moscow, Russia \\ ${ }^{2}$ College of Liberal Arts and Social Studies, East Central University, Ada, Oklahoma, USA
}

\author{
Article history \\ Received: 11-09-2015 \\ Revised: $18-09-2015$ \\ Accepted: 09-10-2015 \\ Corresponding Author: \\ Alexander Aref'ev \\ Center for Sociological \\ Research, Ministry of \\ Education and Science, \\ Moscow, Russia \\ Email: alexander.arefiev@gmail.com
}

\begin{abstract}
The article focuses on the main trends in American students training in Russia from the 1960s to the present day. The paper considers the issues like changes in geography and curricula of American students, dynamics of their total number in Soviet and Russian higher education and their preferences of certain universities. The article also provides information on socio-demographic composition of American students in Russia, tuition fees and daily expenses. The authors discuss the level of training satisfaction as well as identify revenues American students bring in Russian economy. The paper relies on archival data of the USSR Ministry of Higher Education Institutions, current Russian and American statistics and the results of a pilot sociological study $(\mathrm{N}=237)$ which the authors carried out in May 2015. The authors drew a conclusion about the decline in the US youth interest to studying in Russia. In this regard they propose a list of measures aimed at intensification and amplification of RussianAmerican exchange programs.
\end{abstract}

Keywords: Education, Youth, Russian Universities, American Students

\section{Introduction}

Academic exchange programs which provide students, post-graduates and interns with an opportunity for studying abroad is one of the areas of RussianAmerican humanitarian cooperation. These programs are an important tool for promoting better understanding between nations and facilitating successful development of bilateral relations. Even a short-term academic visit to a country can equip a person with a perspective, totally different from one imposed by the media, books or movies. Visiting Russia is especially beneficial to those studying Russian language.

Studies of academic cooperation mainly focus on analyzing bilateral academic programs and projects (Dmitriev et al., 2008). They consider dynamics of Russian universities participation in such programs as Fulbright, IREX, Muskie, Young Leaders etc and the number of people participating in these programs. These papers also cover activities of alumni associations of Russian students who studied in US universities and publish interviews where American students share their impressions about studying in Russia and Russian students-about the US (MSU, 2004; RACHE, 2007). In addition, the studies explore such issues as practices of American colleges and universities regarding international students enrollment (Tkach and Fillipov, 2014), methodology of teaching various subjects, students' system of values. A truly useful practical guide for promoting bilateral humanitarian cooperation with Russia which has been recently published in the USA is aimed at American colleges and universities and gives a detailed description of special features of Russian system of higher education. The book also contains practical recommendations on finding a partner Russian university, establishing contacts with it and suggests possible models of cooperation and ways of funding them (IIE, 2015a). At the same time, there have been practically no if any publications about the dynamics of the number of American students, interns and postgraduates in Russia, changes in their academic preferences etc. A unique research carried out in 19841990 by American Council of Teachers of Russian and the Foreign Language Center at the Hopkins University seems to be a rather unusual one: It was a survey of 658 American students and post-graduates who studied Russian language in Soviet universities in 1894-1990 (Brecht et al., 1993; Brecht and Robinson, 1995) and a repeated survey, carried out about 20 years later which embraced 1900 young Americans who had been coming to Russia for 15 years for 2, 4 and 9 month language programs, organized by ACRT/ACCELS (Davidson, 2010). 
However, both of these papers focused primarily on the issues of studying Russian as a second or foreign language.

Most comprehensive data on American students abroad, including Russia, has been collected and published since 1950 s by the Institute of International Education (IIE, 2015b). In Russia this information has been collected and published since 2003 by the Center of Sociological Studies at the Ministry of Education and Science of the Russian Federation (TFCHEIRF, 2015; ERES, 2015). Some of its publications were devoted to American citizens studying in the Russian Federation in certain years (Sheregi et al., 2002; Aref'ev, 2007; CSS, 2014). However, till present moment there have been virtually no papers with a systematic approach to available statistical data or those highlighting main trends in Americans training in various programs in Russian universities from the days of the Soviet Union till today, sociological methods haven't been used in the research either (in the USSR, due to a closed nature of the society, the information on foreign citizens was not published or it was published marked as "Not for public use"). Papers devoted to teaching international students in Soviet universities, published in Russia, neither identified nor gave a detailed analysis of American students body (TSFCRPSDP, 1999; Belov, 2003). The focus of this paper is statistical and sociological analysis of American students, interns and post-graduates training in Russia over the period of recent 50 years.

\section{Materials and Methods}

The article aims at defining main trends in Americans training in Soviet and Russian institutions of higher education.

Objectives of the research are the following:

- Analyzing the dynamics of total number of American students in Russian higher education

- Comparative analysis of most popular courses and majors of American male and female students in Soviet and post-Soviet periods

- Investigating the geography of American citizens' training in Russia and defining educational institutions they Preferred best

- Estimating revenues for Russian economy from training American students

- Defining main socio-demographic features of Americans, undergoing educational programs in Russia, their sources of information about Russian higher education and reasons for studying in Russian Universities

- Determining chief problems of adaptation period, degree of satisfaction with professional training and accommodation American young men and women receive in Russian universities

- Studying opinions of American students, interns and post-graduates on employment prospects in the USA with a degree of a Russian university and the benefits for professional development gained as a result of an academic visit to Russia as well as their plans to keep in touch with their Russian Alma Mater in future

- Defining the ratio of American students-graduates from a Russian university-who would recommend their friends to follow their example, that is to study in Russia

- Comparison on a number of factors with Russian students studying in the USA

Archival materials of the department statistics of the USSR Ministry of Higher Education and Ministry of Education and Science of the Russian Federation as well as statistical data of the Institute of International Education (the USA) formed the basis for this research.

To solve the research tasks the authors used two methods: Statistical and sociological.

The statistical method included the systematization and analysis of departmental statistics provided by the authors relating to the US students who received their education in Russia (the USSR) over the last 50 years, this information was collected officially and according to a uniform standard and archived by the USSR Ministry of Education and the Ministry of Education and Science of the Russian Federation. The data from the Institute of International Education (USA) were also used as reference data.

To obtain additional information of motivating and behavioral character about the American students currently studying in Russia, which was necessary to identify the nature and reasons for their arrival in Russia today for training and to assess the degree of satisfaction with living and education conditions, in April-May 2015 a selective sociological survey of 237 US citizens studying in Russian universities under various programs was conducted. The sample size makes $6.0 \%$ of the total number of US students of Russian higher educational institutions. For the selection of respondents quota sampling was applied, proportional to the number of American students in $95 \%$ of institutions where they had been trained (are being trained) and in proportion to their number according to the courses (years) of study. The sociological survey was a benchmark one in nature and was designed to identify trends, without absolute priority given to the conclusions (García-Galán et al., 2012; Testa et al., 2015).

\section{Results}

\section{Information on Americans Studying in Universities of the Soviet Russia}

Relations in the field of education between the USA and Russia as systematic exchange programs for students and post-graduates began only after WWII. First American students and post-graduates came to study in 
the USSR in the late $50 \mathrm{~s}$ to the Leningrad State University (12 people) and Lomonosov Moscow State University mainly for studying Russian language. In the 1960s the number of American students in the Soviet Union slightly increased. From 1962 Soviet institutions of higher education enrolled several dozens of Americans (students and post-graduates) annually, as a rule, for no longer than one or two semesters (Table 1).

In addition to the Leningrad State University which in the 1960 s taught more than $90 \%$ of American students and post-graduates on various academic programs (Philology, History, Natural Sciences, Art Appreciation etc.), as well as the Moscow State University with several American students, Americans also began entering the All-Union State Institute of Cinematography, Tchaikovsky Moscow Conservatory, Rimsky-Korsakov Leningrad Conservatory, Komistas State Conservatory of Yerevan.

In 1972 regular academic exchange programs were legally stated in the Agreement on Cooperation in Technology and Education between the USSR and the USA and since the second half of the 70s the number of American young men and women arriving every year in the USSR with academic purposes exceeded 100 people, in 1980 reaching the record figure of 346 people. The total number of Americans studying in the Soviet universities in the period from the 1970s through 1980s (mainly doing short-term academic programs) equaled 868 people and the center of their "academic attraction", like in the 50 and $60 \mathrm{~s}$, was the Leningrad State University. The following is conclusively illustrated by the graduation statistics of American students, doing various programs of 6 months and longer, the outcome of which was obtaining diplomas and academic degrees in Soviet higher education (Table 2).

In the first half of the 1980s (from 1981 through 1985) the number of American students studying in Soviet universities on programs longer than 6 months equaled 884 people (with about 200 people arriving every year). They still preferred short-term programs (the number of Americans studying for longer than a semester did not exceed 15\%). The geography of Americans training became more varied: It wasn't only Leningrad, Moscow, Kiev, Yerevan, but universities in the cities of the Russian Soviet Federative Socialist Republic and other union republics. During the collapse of the USSR in 1992, more than 1000 Americans were studying in 48 universities in 20 cities.

The survey, carried out in the USA among 658 Americans who had studied in the USSR in 8 universities of Moscow and Leningrad on short-term (one semester) programs of Russian language from 1984 to 1990, provided information about the students' average age (21.8) and sex distribution: $58 \%$ of students were females and 42\% -males (Brecht et al., 1993).
Table 1. American students' enrollment and graduation from the USSR universities in 1962-1970, number of people

\begin{tabular}{ll}
\hline Years of studying & Enrollment/Graduation (people) \\
\hline 1962 & $29 / 28$ \\
1963 & $32 / 32$ \\
1964 & $35 / 33$ \\
1965 & $28 / 27$ \\
1966 & $32 / 28$ \\
1967 & $35 / 31$ \\
1968 & $40 / 28$ \\
1969 & $49 / 10$ \\
1970 & $0 / 2$ \\
Total & $180 / 220$ \\
\hline
\end{tabular}

Table 2. Distribution of American students studying for more than 6 months and graduating from various Soviet universities in the $1970-1980 \mathrm{~s}$

\begin{tabular}{lc}
\hline University names & $\begin{array}{c}\text { American } \\
\text { graduates, }\end{array}$ \\
Leningrad State University & 203 \\
Tchaikovsky Moscow Conservatory & 11 \\
Kiev State University & 6 \\
Moscow State University & 5 \\
All-Union State Institute of Cinematography & 3 \\
Komitas State Conservatory of Yerevan & 2 \\
Yerevan State University & 2 \\
Kiev National University of & \\
Construction and Architecture & 2 \\
Rimsky-Korsakov Leningrad Conservatory & 1 \\
Gnessin State Musical College & 1 \\
Vaganova Academy of Russian Ballet & 1 \\
Moscow Automobile and & \\
Road Construction University & 1 \\
Plekhanov Institute of the National Economy & 1 \\
Leningrad State Forest Technical Academy & 1 \\
Total & 240 \\
\hline
\end{tabular}

There is no information about social composition of American students in the USSR; however, it is known that representatives of so-called "lower-classes" were given a priority when entering Soviet universities (that is, from the families of workers, farmers and employees) which made up about $70 \%$ of all international applicants (CW, 2007).

\section{Courses done by American Students and Post- Graduates in the USSR}

It seems reasonable to investigate courses studied by Americans in Soviet universities in the period from 1962 to 1992 . The data for the research was taken from the statistical information on 518 American graduates who did university courses in the USSR for longer than 6 months (the total number of Americans in Soviet universities from 1962 to 1992 , which did mainly shortterm courses, sometimes for not more than a month, was about 2,800 people).

Analysis of the groups' make-up on long-term programs in the indicated time period demonstrated that 314 people (or $60.6 \%$ ) were post-graduates, who were collecting research data in the USSR and were working on 
post-graduate papers on various themes, while 204 people were doing specialists degree. There are considerable differences among these two groups of American students regarding their academic and scientific areas of study. In this regard, most common courses done by undergraduates were Russian language and Literature as well as Culture and Art (Table 3). As for humanities, most often students chose history, among medical courses-it was general medicine, in economics-economic and social planning, foreign economic relations and economic cybernetics, in engineering-mining machinery and resource development. American students doing long-term academic programs were not interested in courses in education, jurisprudence or agriculture, forestry and fishing.

Post-graduates chose different majors. The most popular one was humanities-done by every second student. While most post-graduates working in humanities were studying and collecting information on the history of the Communist Party (112 persons or $35.7 \%$ post-graduates), others majored in world history (16 persons), ethnography (7 persons), archeology (3 people), history of philosophy (2 persons) and psychology (1 person). Russian and Soviet multinational literature took the second place on the list of American postgraduates' preferences, the third went to Russian and other Slavic languages as well as languages of Soviet peoples. It is also worth mentioning that several people studied political economy, that is, Marxism economic theory, as a part of their economic education (Table 4).

Most American students did Russian language and literature in the Leningrad State University, while they preferred to study languages of the peoples of the USSR and national Soviet literature in the universities of different national autonomies, for example, Tatarian Autonomous Soviet Socialist Republic (ASSR), Chuvash ASSR and others. This became possible in the 1980s and early 1990s.

\section{Data on Americans Studying in Post-Soviet Russian Universities}

Booming interest of American students to Russia, Russian language, culture, its social and political life fell on the years of perestroika and events after it that led to the collapse of the USSR. Suffice to say, right after "break-up" of the Russian Federation and the former Soviet republics, the number of American young men and women studying in the universities of the new Russia increased significantly and in the 1993/1994 academic year totaled to 1,512 people (whereas in other universities of the former USSR there were only 139 American students, of which 50-in Ukraine, 37-in Estonia, 14-in Latvia and 13-in Kazakhstan). However, quite soon this interest to Russia somewhat declined and in the 1995/1996 academic year the number of Americans in the country's universities went down to 1,290 people and later, in the 2000/2001 academic year-to 1,152 students. Dynamics of the number of Americans studying in Russian universities is represented with the following data (Fig. 1).
* Prepared based on the data of the Institute of International Education (IIE, 2015b) for 2000/01-2007/08 and the Center for Social Research of the Ministry of Education and Science of the Russian Federation (ERES, 2015) for 2008/09-2013/14 academic years.

In the 2013/2014 academic year, Americans applied for educational services of 107 Russian universities located in 42 cities of the Russian Federation. Though ten years ago practically equal number of US students attended universities in Moscow, St. Petersburg universities and other regions, recently they have begun to give a decided preference (like in the Soviet period) to the universities of St. Petersburg (Fig. 2).
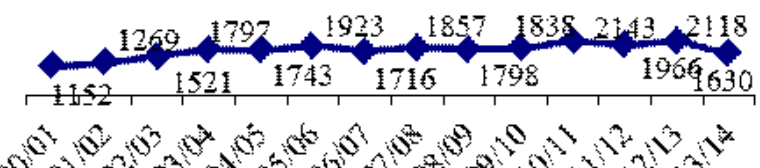
के की

Fig. 1. Changes in American students, interns, graduates body enrolled full-time in Russian universities in 2000/20012013/2014 academic years*

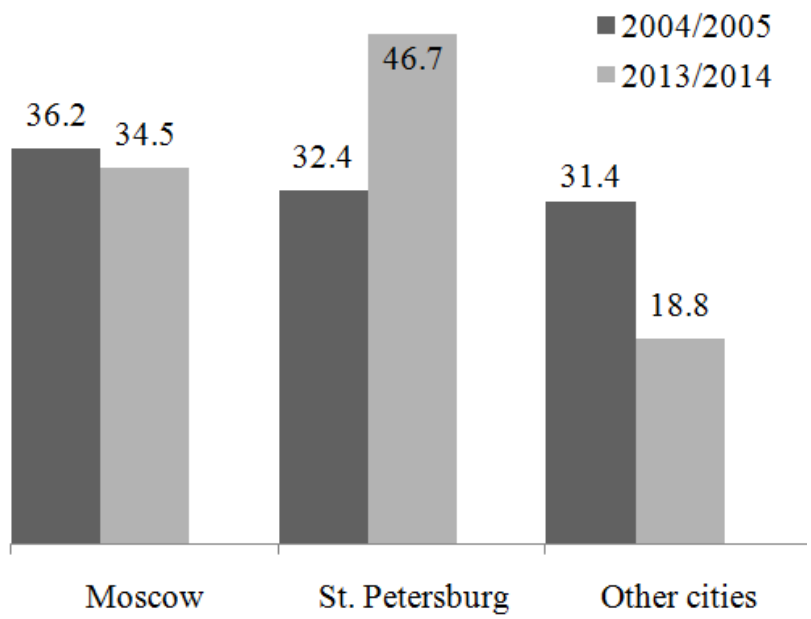

Fig. 2. The ratio of American students, interns, graduate students enrolled in universities of Moscow, St. Petersburg and other Russian cities in 2004/20052013/2014 academic years, $\%$

Table 3. Courses done by American students (studying for more than 6 months) in Soviet universities in 1962-1992

\begin{tabular}{lcc}
\hline Courses & $\begin{array}{c}\text { Q-ty of students } \\
\text { (persons) }\end{array}$ & $\begin{array}{l}\text { Students' } \\
\text { percentage (\%) }\end{array}$ \\
\hline Russian language and literature & 76 & 37.2 \\
Culture and art & 58 & 28.4 \\
Humanities & 14 & 6.9 \\
Medicine & 13 & 6.4 \\
Economics & 6 & 2.9 \\
Engineering and technology & 3 & 1.5 \\
Physics and mathematics & 2 & 1.0 \\
Major not defined & 32 & 15.7 \\
Total & 204 & 100.0 \\
\hline
\end{tabular}


Table 4. Courses chosen by American post-graduates (with duration of more than 6 months) in Soviet universities in 1962-1992

\begin{tabular}{|c|c|c|}
\hline Field of study & $\begin{array}{l}\text { Q-ty of students } \\
\text { (persons) }\end{array}$ & $\begin{array}{l}\text { Students' } \\
\text { percentage (\%) }\end{array}$ \\
\hline Humanities & 149 & 47.5 \\
\hline Russian literature and multinational soviet literature & 84 & 26.7 \\
\hline Russian language, Slavic languages and languages of the USSR peoples & 45 & 14.3 \\
\hline Law & 14 & 4.4 \\
\hline Economic science & 7 & 2.2 \\
\hline Art & 5 & 1.6 \\
\hline Science & 4 & 1.3 \\
\hline Engineering and technology & 3 & 1.0 \\
\hline Medicine & 3 & 1.0 \\
\hline Total & 314 & 100.0 \\
\hline
\end{tabular}

Table 5. Cities with universities with the largest number of American students in the 2013/2014 academic year

\begin{tabular}{lccc}
\hline & $\begin{array}{c}\text { The number of universities, } \\
\text { providing training to } \\
\text { American students }\end{array}$ & $\begin{array}{c}\text { Q-ty of American } \\
\text { students, (persons) }\end{array}$ & $\begin{array}{c}\text { Ratio of American } \\
\text { students, \% }\end{array}$ \\
\hline Sities & 15 & 762 & 46.7 \\
Moscow & 25 & 563 & 34.5 \\
Irkutsk & 3 & 44 & 2.7 \\
Kazan & 3 & 30 & 1.8 \\
Yaroslavl & 2 & 23 & 1.4 \\
Petrozavodsk & 1 & 21 & 1.3 \\
Ufa & 3 & 17 & 1.0 \\
Nizhny Novgorod & 2 & 15 & 0.9 \\
Izhevsk & 1 & 14 & 0.9 \\
Volgograd & 3 & 13 & 0.8 \\
Arkhangelsk & 1 & 12 & 0.7 \\
Perm & 2 & 12 & 0.7 \\
Vladivostok & 2 & 10 & 0.6 \\
Other cities & 44 & 94 & 5.8 \\
Total & 107 & 1,630 & 100.0 \\
\hline
\end{tabular}

The geography of American students training in Russia is quite broad: Apart from Moscow and St. Petersburg, at present they are studying in Abakan, Arkhangelsk, Barnaul, Chelyabinsk, Chita, Vladivostok, Vladimir, Volgograd, Voronezh, Izhevsk, Irkutsk, Kazan, Kemerovo, Kolomna, Kostroma, Krasnodar, Krasnoyarsk, Kursk, Makhachkala, Nalchik, Nizhny Novgorod, Novosibirsk, Omsk, Orenburg, Penza, Perm, Petrozavodsk, Pskov, Pyatigorsk, Rostov-on-Don, Saratov, Tver, Tomsk, Ulan-Ude, Ulyanovsk, Ufa, Yakutsk, Yaroslavl, Yekaterinburg. Most universities of these cities are teaching just a few US citizens and only in 13 cities the student body exceeds 10 people (Table 5).

The overall number of Americans in the body of foreign students, interns, full-time post-graduates in Russian higher education, which in the 2003/2004 academic year amounted to $2.7 \%$, went down to $1.0 \%$ in $2013 / 2014$ and on the list of the countries, most attractive to Americans in terms of education, in 2003 Russia held 18th place (after South Africa and Greece), ten years later-in 2013, -it was on the 34th place (after Cuba and Switzerland). As a comparison, the number of Russian students in US universities and colleges, reaching its peak in 7025 people in the 1999/2000 academic year, a few years later it went down to 5000 people, remaining practically unchanged over the past 10 years $(5,138$ people in $2013 / 2014)$, while the proportion of Russians in the total number of foreign students in the USA in 1999/2000-2013/2014 years has decreased from 1.4 to $0.6 \%$ (IIE, 2015b). In the same way, American universities that used to be most attractive to Russian students in the 90s, have lost by now their leading position to the universities of China and Germany.

\section{Universities Chosen by Americans for Training in Post-Soviet Russia}

Almost all universities with a large number of American students (40 or more people) are located in St. Petersburg and Moscow (Table 6).

Distribution of American students, interns and postgraduates in Russian universities with different departmental affiliation (proprietary format) in the 2013/2014 academic year was as follows:

- $\quad 38.5 \%$ (627 persons)-Russian Ministry of Education and Science (71 universities)

- $54.5 \%$ (888 persons)-universities of other departmental affiliation: (26 universities) 
- $0.1 \%$ (2 people)-universities of federal subjects and municipal universities (two universities in Moscow region)

- $\quad 6.9 \%$ (113 persons)-non-governmental universities (8 universities in Moscow and St. Petersburg including two universities with religious affiliation)

\section{Programs and Majors American Students are Doing in Russian Universities at Present}

US citizens apply for Russian higher education mainly as interns on academic exchanges programs which on average last for one semester (exchange education). In Russia, long-term specialist degree programs are chosen mainly by those Americans, who study art and culture or medicine. There are very few students who opt for Russian Bachelor or Master degrees (mainly in St. Petersburg and Moscow State Universities) and virtually no one is interested in Russian post-graduate programs. The situation remains basically the same since the 2004/2005 academic year (Fig. 3).

At the same time, the ratio of majors chosen in the past decade has changed, basically due to Russian language which in the 1990s and early 2000s was the main subject and the reason why young Americans applied to Russian universities (Fig. 4).
In this regard we can observe a similar clear tendency of declining interest in studying Russian language in US colleges and universities: In 1990 it was studied by 44,476 students, but in 2009 there were only 26,753 students, in 2014-21,962 (Goldberg et al., 2015).

We can conclude that, like in Soviet times, humanities remain the main area American students, interns; post-graduates apply for to Russian universities. At the same time, if compared to the Soviet period, there is a decrease in the interest to studying modern Russian literature as well as modern Russian political history as a part of political science (as we have mentioned before, most attractive subjects for hundreds of US post-graduates in Soviet universities in the 1960-1980s were mainly the history of the Communist Party, the Soviet and Russian literature). By contrast, out of 9 American postgraduates studying in Russian universities in the 2013/2014 academic year 4 majored in humanities, 1in social sciences, 3-in art and culture and 1 in Technology (Metallurgical Engineering).

Along with this, more students choose to study philology, psychology, world history, ethnography, international relations, social work and some other humanities and social courses.

Table 6. Russian universities enrolling the largest number of full-time American students in the 2013/2014 academic year (persons)

\begin{tabular}{llc} 
University name and its departmental affiliation/proprietary format & University & $\begin{array}{c}\text { Q-ty of American } \\
\text { students, (persons) }\end{array}$ \\
\hline St. Petersburg State University (Russian Government) & St. Petersburg & 462 \\
Moscow State University (Russian Government) & Moscow & 176 \\
St. Petersburg State Polytechnic University (Ministry of Education and Science) & St. Petersburg & 133 \\
Moscow Art Theater School (the Ministry of Culture) & Moscow & 88 \\
Russian Academy of National Economy and Public Administration (Russian President) & Moscow & 68 \\
Russian State University for the Humanities (the Ministry of Culture) & Moscow & 66 \\
Herzen State Pedagogical University of Russia (Ministry of Education and Science) & St. Petersburg & 59 \\
Higher School of Economics (Ministry of Education and Science) & Moscow & 49 \\
European University at Saint Petersburg (Non-governmental) & St. Petersburg & 48 \\
International University in Moscow (Non-governmental) & Moscow & 40 \\
\hline
\end{tabular}

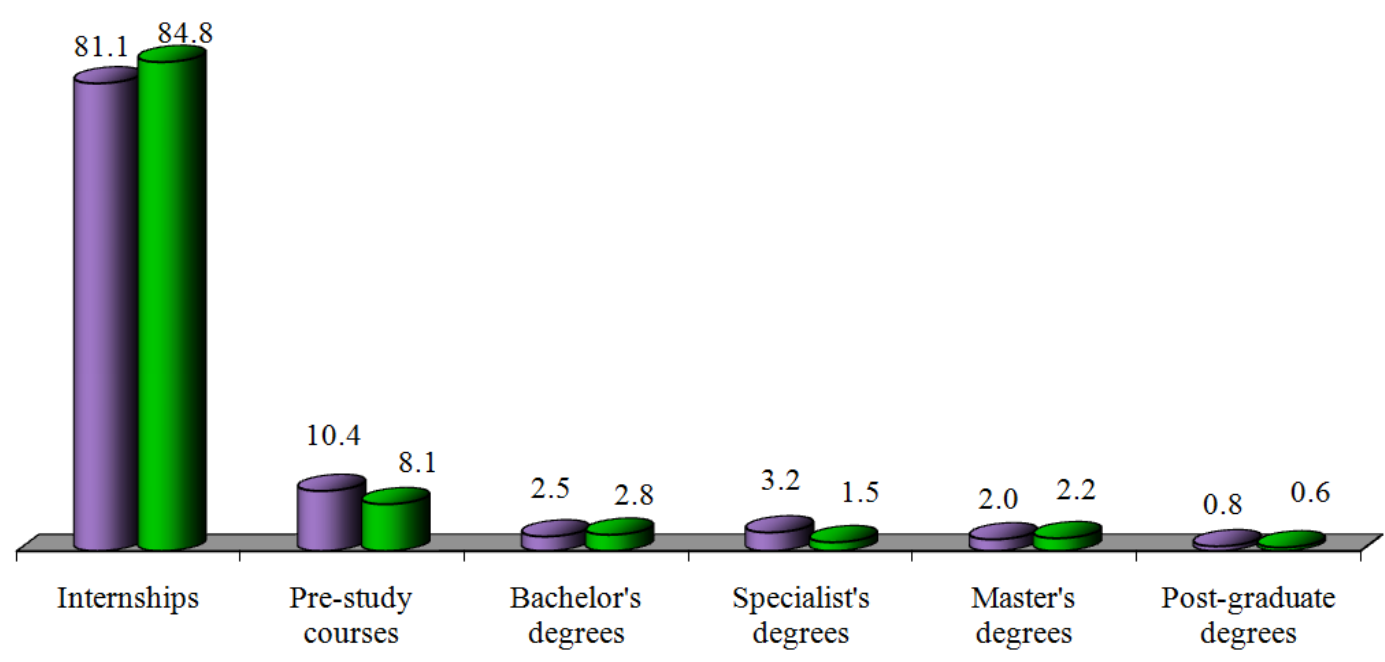

Fig. 3. Educational programs for American citizens in Russian universities in 2004/2005 and 2013/2014 academic years, \% 


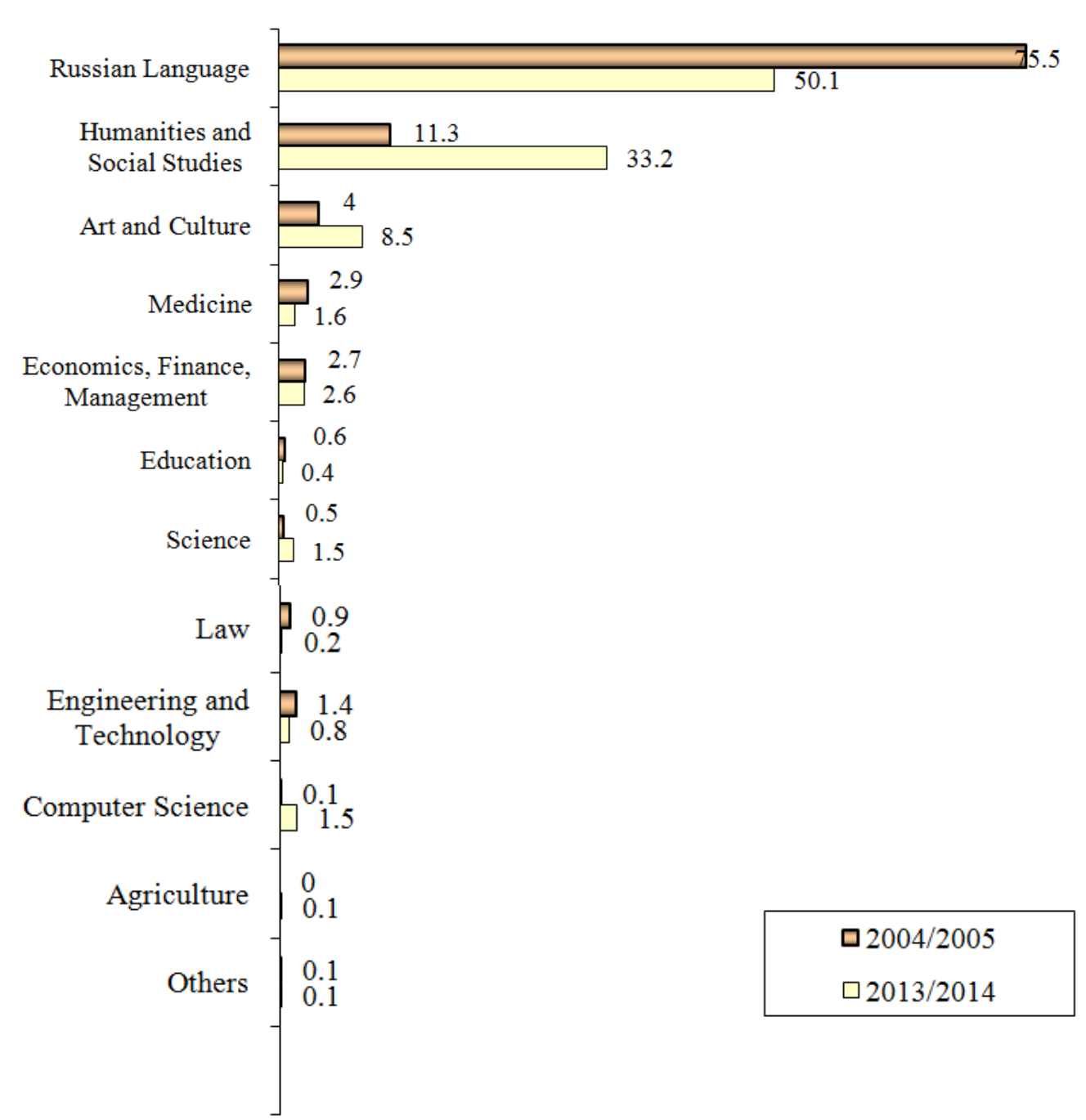

Fig. 4. Basic types of courses done by full-time American students in Russian universities in 2004/2005 and 2013/2014 academic years, $\%$

Marxist economic theory, as well as the history of the Communist Party and Scientific Communism, was excluded from university curricula (majors)-those subjects American students could apply for during the Soviet times are now not studied even by Russian students.

In some cases, certain short-term academic programs American students do in Russian universities are just a formal reason to visit Russia in order to get acquainted with its historical and cultural places of interest.

It is also worth mentioning a small number of US citizens studying in Russia on external tertiary programs (61 people in the 2013/2014 academic year, practically all of them in Moscow universities). Most popular courses in Russian universities they did by correspondence are the following: Culture and Art (51 persons), Economics, Finance and Management (5 persons), Humanities (3 persons), Law (1 person) and Russian Language (1 person).
Besides, 11 young Americans were receiving vocational secondary education, mainly in the field of art and culture (ballet, music, singing).

\section{Discussion}

Americans are interested in the options of distance learning in Russia, especially Russian language. Thus, as on July 1, 2015 about 20 Americans registered on the learning portal "Pushkin Online" of the Pushkin State Institute of Russian Language (the courses of advanced studies for Russian teachers).

By contrast, nowadays business and management are the most attractive subjects to Russians studying full-time at American universities. Over $80 \%$ of them study on long-term programs, including $40.8 \%$ doing Bachelor degrees and 39.7\% -Master's and Doctor's. In addition to Russian students, 1136 Russians were studying on intensive language programs in 2013 in 
the USA and 1138 Russians scholars, were doing research or teaching jobs in US universities. In 2003 the number of Russian scholars in the United States was 2403 people, that is, over the last 10 years it has fallen by more than twice (IIE, 2015b).

Up to $90 \%$ of students and interns and half of US post-graduates receive educational services on the contract basis they pay for training in Russian universities from their own funds or with grants or tuition fees are paid by the companies which sent them to study in Russia) and only $10 \%$ receive free education, mainly in the framework of inter-university academic exchanges carried out free of charge. The average cost of training for American citizens in Russian universities in the $2013 / 2014$ academic year was slightly more than USD 5,000; USD 4,100 for students and post-graduates and USD 5,800 for interns. The highest was the cost of their education in the St. Petersburg Academy of Russian Ballet (USD 13,500 for a 10-month training), besides up to USD 10,000 (and sometimes even more) for a number of programs and courses in the Moscow State University, St. Petersburg State University and Moscow State Institute of International Relations. The cost of training in regional universities and on short-term courses of Russian language was considerably lower (up to USD 3,000$3,500)$. The price for correspondence courses was also lower (almost twice as low) than full-time.

Total revenues from training American citizens in Russian universities and their stay in Russia in the 2013/2014 academic year were estimated approximately as RUB $470 \mathrm{mln}$ or USD $15.7 \mathrm{mln}$ (USD $8.2 \mathrm{mln}$ was the total cost of training and USD $7.5 \mathrm{mln}$-living costs, at approx. USD 500 per month for food, shelter, transport, leisure, health care etc.). By comparison: In the same year the contribution 5,138 Russian students at American colleges and universities made to the US economy amounted to approx. USD $156.6 \mathrm{mln}$.

In April and May 2015 the Center for Sociological Research at the Russian Ministry of Education and Science conducted a sociological survey based on a representative sample of 237 American young men and women enrolled full-time in Russian universities (192 interns, 40 undergraduates and students at pre-study courses, 5 post-graduates), $4 / 5$ of whom were trained in universities of big cities (Moscow and St. Petersburg) and a fifth-in universities in other cities. As for gender composition, $2 / 3$ of those surveyed were males, 1/3females (by comparison, more than half of US students studying abroad are women). The average age of the respondents was 22.5 (where students are 22.1 years old, interns-22.9, post-graduates-26.6).

Social background of American men and women who came to study in Russia is heterogeneous. More than half of those surveyed come from the families of humanitarian and technical professionals, almost every fifth father (and 3\% of mothers) are entrepreneurs, businesspeople, owners of a company or a store. One in four fathers (and 30\% of mothers) are mid-level officials, police officers, military, engaged in services, workers, farmers, retired, housewives or unemployed. $6 \%$ come from the families of executives (top managers, congressmen, senators, diplomats, politicians).

According to the self-assessment of the respondents, $77 \%$ of them come from middle-income families, $18 \%$-from families with high income, 5\% from low-income families.

The survey identified two main reasons (motives) why American men and women came to study in Russia: (1) higher tuition fees in US universities; (2) their wish to study in Russia, which was mentioned by almost half of the respondents, mainly by those specializing in Russian language and Russian culture.

American colleges, universities or companies that sent students to Russia and the Internet were named as the main sources of information about a particular Russian university where the respondents are studying.

American young men and women preferred universities of Moscow and St. Petersburg as it is believed that "they give higher quality instruction and more prestigious diplomas, besides there are many wellknown attractions there," while provincial universities attract with more moderate tuition fees and the cost of living which is not as high as in capital cities.

The main difficulties American students, interns and post-graduates face during the first days and weeks after arriving to study in Russia are mainly connected with a poor knowledge of Russian language (for most of those who didn't study it as their major) as well as domestic issues (unusual food, unfamiliar living conditions, cold climate).

As a rule, the vast majority of respondents (3/4) begin to study Russian language from a beginner level in the US or Russian university. Only $15 \%$ studied it at school, while for one in ten respondents Russian was his or her mother tongue, they knew it from childhood. Thus, at least $10 \%$ of American students, interns and post-graduates, coming to study in Russia, have Russian roots and come from families that immigrated to the United States from the former Soviet Union and Russia.

More than half of the respondents lived at the university dorms during their training (an average of two people per room), about a third rented a room or an apartment and practically one in ten lived with their relatives or friends.

The monthly accommodation payment for the dorm in April 2015 was about RUB 7,100 or USD 130. About $2 / 3$ of the respondents were more or less satisfied with living conditions in the dorms.

The key issue of the research was quality assessment of vocational training obtained in Russian universities. It was fully in line with expectations of $85 \%$ of the surveyed students, 64\% interns and all post-graduate, 
was partly satisfactory for $15 \%$ of students, $34 \%$ interns, while only $2 \%$ of the interns indicated that their vocational training did not meet their expectations.

Management and the quality of training, friendly Russian students and teachers were named by the respondents as most positive sides of studying at their university, while critical marks were mainly referred to the condition and equipment of classrooms and laboratories, university canteens, cafes, cafeterias. Besides, the respondents noted drawbacks in the organization of field internship (especially for students studying at English language programs).

In 2015 tuition fee among surveyed students was an average of USD 4,500, for interns-USD 6,400, for postgraduates-USD 3,900. It was considered very high by $20 \%$ of students and $25 \%$ of interns, a normal one- $38 \%$ of students and $68 \%$ of interns, low- $12 \%$ of students and $7 \%$ of interns. At the same time the majority of postgraduates considered the cost of their education too high.

One third of students surveyed and two thirds of post-graduates had a part-time job which brought them an average of RUB 15,000 per month (USD 273). In this regard, it should be noted that since 2015 Russia canceled the existing job restrictions for foreign students and postgraduates (previously they could work only for their university).

When being asked about their career prospects, 9 out of 10 undergraduates and post-graduates said that they are planning to return home after graduation, only one in ten considered the possibility of employment in Russia or another country. For some respondents, their plans of a longer stay in Russia were determined by their intention to continue training in Russian universities at the next level.

At the same time, four out of five surveyed postgraduates stated that they would not have any difficulties when looking for a job with a Russian PhD diploma and only one post-graduate (studying at the Peoples' Friendship University of Russia on a course of Neurology) said that Canada, where he was going to apply for a job, does not recognize Russian diplomas.

Most interns $(85 \%$ of which were students of American colleges and universities, mainly seniors) were certain that their academic visit to Russia would to some extent keep promoting their professional career since many US employers consider it as an advantage if an applicant has a university degree with an experience of studying abroad for at least a semester or a year.

All surveyed American students and post-graduates $(100 \%)$ and $94 \%$ of interns, after returning home, will recommend their friends to go to Russia for training in the same university on the same course.

Besides, the respondents provided some feedback with recommendations to Russian universities. First of all, students and post-graduates would like to improve living conditions in the dorms (including free $\mathrm{Wi}-\mathrm{Fi}$ ) and the work of university canteens as well as have a wider use of English language in the instruction and more literature in English in the libraries. The main recommendation of the interns was to increase the effectiveness and intensity of Russian language training (which would also include settling them in the dorms together with Russian students for a deeper immersion into the language and, thus, being able to master Russian sooner) and to improve the organization and content of instruction (that is, make it more modern, meeting standard international requirements, to reduce the number of non-core subjects, to introduce a number of new courses, to form groups on the basis of their level, etc.), as well as to provide more practical classes.

\section{Conclusion}

Over the last decade Russia has become a less attractive country for Americans in terms of training (the same is with the USA for Russians). This process is also determined by cooling in the bilateral relations. The number of Americans attending Russian universities in the 2013/2014 academic year was 25\% lower compared with the previous year. There is practically no increase in the number of Russian students in US universities and colleges, although in absolute ratio their number is more than 3 times higher than the number of Americans in the Russian higher education. Revenues of the US economy from providing educational services to Russian citizens is almost 7 times higher than the economic contribution of American students in Russian economy, which can also be explained by the higher cost of education and life in the United States compared to Russia.

In comparison with the Soviet period, the number of US post-graduates in Russian universities has decreased significantly. More than $80 \%$ of American students come to Russia on short-term internship programs, while young Russians studying in the United States mainly do 2-4 year tertiary programs.

While in Soviet times young Americans came to universities to study a wide range of courses (mostly humanities) and Russian language was studied by at least half of them, after the collapse of the Soviet Union, their interest to Russian language became the main motivation of coming to Russia: In the 2004/2005 academic year about $75 \%$ of Americans chose this subject. However, in recent years, the number of people who wanted to specialize in Russian language has decreased.

The overwhelming majority of American students, interns and post-graduates are quite satisfied with the quality of vocational training in Russia (if taking into consideration its price), they are planning to stay in touch with their Russian Alma Mater and, upon returning in the USA, will recommend their friends to study in Russia. One in ten American students comes from a family of immigrants from Russia and the former USSR. 
Development of Russian-American academic exchange programs requires agreed efforts of both sides for a better distribution of information on opportunities and terms of international students training in national universities, statistical and sociological monitoring of this process to identify existing problems and timely action to address them. In this regard, carrying out a large-scale opinion poll (with a "mirror" questionnaire) among American students in Russia and Russians-in the United States and publishing its results for discussion may be extremely beneficial. Constant monitoring of cooperation of Russian and American universities seems also quite viable.

\section{Acknowledgement}

This study was carried out as a part of scientific program of the Center for Sociological Research, approved by the Ministry of Education and Science of Russia in 2015.

\section{Author's Contributions}

Alexander Aref'ev: Developed the plan of the research and carried out the study, data collection of the study sample, analysis and writing of the manuscript.

Mara Sukholotskaya: Participated in the results analysis, contributed to the drafting of the article and provided critical reviewing for significant intellectual content.

\section{Ethics}

This article is original and contains unpublished material. The corresponding author confirms that all of the other authors have read and approved the manuscript and no ethical issues involved.

\section{References}

CW, 2007. 200 Years of Russian-American Relations: Science and Education. 1st Edn., Collected Works, OLMA Media Grupp, Moscow, ISBN-10: 9785373017183, pp: 400.

Aref'ev, A.L., 2007. Russian Universities on the International Market of Educational Services. 1st Edn., Social Forecasts and Marketing Center, Moscow, ISBN-10: 9785373017572 , pp: 700.

Belov, V.A., 2003. Training of Foreign Citizens in Russia: History, Challenges and Opportunities. 1st Edn., Peoples' Friendship University of Russia, Moscow, ISBN-10: 5209002265x, pp: 443.

Brecht, R. and J. Robinson, 1995. On the Value of Formal Instruction in Study Abroad: Student Reactions in Context. Second Language Acquisition in a Study Abroad Context, Freed, B.F. (Ed.), Amsterdam /Philadelphia: John Benjamins Publishing Company, ISBN-10: 1556195435, pp: 317-334.
Brecht, R., D. Davidson and R. Ginsberg, 1993. Predictors of Foreign Language Gain During Study Abroad. 1st Edn., Occasional Papers of the National Foreign Language Center at the Johns Hopkins University, Washington, D.C., pp: 33.

García-Galán, M.M., A. del Moral-Agúndez and C. Galera-Casquet, 2012. Assessing the introduction and development of a designation of origin from the firm's perspective: The case of the Ribera del Guadiana wine PDO. Span. J. Agric. Res., 10: 890-900. DOI: $10.5424 / \mathrm{sjar} / 2012104-2873$

Davidson, D., 2010. Study abroad: When, how long and with what results? New data from the Russian front. J. Foreign Lang. Ann., 43: 6-26. DOI: $10.1111 /$ j.1944-9720.2010.01057.x

Dmitriev, N.M., G.P. Pavlihin, A.V. Talonov and I.V. Fedorov, 2008. International Cooperation of Russian Universities: Challenges and Opportunities. OLMA Media Grupp, Moscow, ISBN-10: 9785796200919, pp: 332.

CSS, 2014. Drawing Up Universities Ranking, International and Russian Practices. 1st Ed., Center for Sociological Studies, Moscow, pp: 504.

ERES, 2015. Statistical Collectiont No 5. 1st Edn., Center for Sociological Studies, Export of Russian Educational Services, Moscow, ISBN-10: 97859006011306 , pp: 416.

Goldberg, D., D. Looney and N. Lusin, 2015. Enrollments in languages other than English in United States institutions of higher education. Modern Language Association of America.

IIE, 2015a. How to Develop Partnerships between U.S. and Russian Universities. 1st Edn., Institute of international Education, New York, ISBN-10: 9780872063778 , pp: 42.

IIE, 2015b. Open Doors 2014: Report on International Educational Exchange. 1st Edn., Institute of International Education, New York, ISBN-10: 0872063712, pp: 144.

MSU, 2004. Professionals for Cooperation. 1st Edn., Moscow State University, Moscow, ISBN-10: 5896550219, pp: 344.

RACHE, 2007. Collection of Works. 1st Edn., OLMA Media Group, Moscow, ISBN-10: 9785373017572, pp: 160 .

Sheregi, F.J., N.M. Dmitriev and A.L. Aref'ev, 2002. Scientific and Educational Potential and Exporting Educational Services of Russian Universities. 1st Edn., Center For Social Forecasting, Moscow, ISBN-10: 5893090047, pp: 552.

Testa, R., M. Fodera, A.M. Di Trapani, S. Tudisca and F. Sgroi, 2015. Choice between alternative investments in agriculture: The role of organic farming to avoid the abandonment of rural areas. Ecological Eng., 82: 227-232. DOI: 10.1016/j.ecoleng.2015.06.021 
Tkach, G.F. and V.M. Filippov, 2014. Procedural, Institutional and Practical Mechanisms of Academic Mobility and Increasing Export of Educational Services. 1st Edn., The Peoples' Friendship University of Russia, Moscow,

ISBN-10: 9785209061397, pp: 288.
TFCHEIRF, 2015. Statistics Digest. No 12. 1st Edn., Center for Sociological Studies, TFCHEIRF, Moscow, ISBN-10: 9785906011306, pp: 416.

TSFCRPSDP, 1999. Research and Methodological Materials. 1st Edn., Radio i Svyaz, Moscow, ISBN-10: 5858130429, pp: 160. 